\title{
Author Correction: Current-controlled nanomagnetic writing for reconfigurable magnonic crystals
}

Jack C. Gartside (1D), Son G. Jung (1), Seung Y. Yoo (D), Daan M. Arroo (1), Alex Vanstone, Troy Dion, Kilian D. Stenning (1) \& Will R. Branford (1)

Correction to: Communications Physics https://doi.org/10.1038/s42005-020-00487-y, published online 30 November 2020.

The original version of this Article contained errors in the author affiliations.

Troy Dion was incorrectly associated with "Cavendish Laboratory, University of Cambridge, Cambridge CB3 0HE, UK" and the affiliation "London Centre for Nanotechnology, University College London, London WC1H 0AH, UK" was inadvertently omitted.

This has now been corrected in both the PDF and HTML versions of the Article.

Published online: 14 December 2020

\footnotetext{
(c) Open Access This article is licensed under a Creative Commons Attribution 4.0 International License, which permits use, sharing, adaptation, distribution and reproduction in any medium or format, as long as you give appropriate credit to the original author(s) and the source, provide a link to the Creative Commons license, and indicate if changes were made. The images or other third party material in this article are included in the article's Creative Commons license, unless indicated otherwise in a credit line to the material. If material is not included in the article's Creative Commons license and your intended use is not permitted by statutory regulation or exceeds the permitted use, you will need to obtain permission directly from the copyright holder. To view a copy of this license, visit http://creativecommons.org/licenses/by/4.0/.
}

(c) The Author(s) 2020 